\title{
НЕОТЕКТОНИЧЕСКАЯ СТРУКТУРА САЛАИРА (ЮГ ЗАПАДНОЙ СИБИРИ) И ЕЕ СООТНОШЕНИЕ С ДОКАЙНОЗОЙСКОЙ СИСТЕМОЙ РАЗЛОМОВ
}

Новиков И. С., Жимулев Ф. И., Поспеева Е. В.

\begin{abstract}
Аннотация
При неотектонической активизации Салаира произошла реактивация крупных, региональных разломов, формирующих общий структурный каркас Алтае-Саянской складчатой области. Активизации подверглась серия дугообразных разломов, очерчивающих структурную дугу Салаира и отделяющих Салаирскую аллохтонную пластину от смежных тектонических зон. Эти разломы, сформированные в позднем палеозое, неоднократно реактивировались в мезозое и испытывают активизацию на неотектоническом этапе. Внутри же Салаирской аллохтонной пластины преобладает хрупкое разрушение, по сети малоамплитудных разрывов, секущих линейные контакты палеозойских надвиговых пластин. Новейшие тектонические нарушения Салаира контролировали эрозионное расчленение территории, что привело к формированию дренажной системы с ярко-выраженным решетчатым рисунком. Амплитуды относительных вертикальных движений на границах между неотектоническими блоками Салаира не превышают 100 м и в новейшей структуре он проявлен как единый мегаблок размером 80 на 250 км. Дифференцированные движения хорошо проявлены на южной, северной и восточной границах мегаблока, где составляют 100-200 м. Северо-западная и юго-восточная границы имеют взбросовый характер, а движения по кулисообразной северо-восточной - наряду с явными признаками взброса имеют также правосдвиговый характер. Толщина Салаирского мегаблока по магнитотеллурическим данным увеличивается с востока на запад с 5 до 15 км в северной части блока и 10 до более чем 20 км в южной его части. Снизу он ограничен зоной низких сопротивлений, которая интерпретируется как зона субгоризонтального разделительного срыва. Формирование нижнего ограничения Салаирского мегаблока произошло в мезозое и лишь активизировано на неотектоническом этапе. Анализ пространственного распределения, деформированности и литологии юрских отложений предгорных впадин вокруг Салаира показывают, что структурный план кайнозойской активизации в целом наследует мезозойский, но отличается от него примерно в 10 раз меньшими масштабами вертикальных смещений.
\end{abstract}

\section{Ключевые слова:}

Морфотектоника, геоморфология, глубинное строение, блоковая делимость, тектоническая расслоенность 
УДК 551.248.2+550.386 + 551.594(271.17)

Новиков $^{1}$ И. С., Жимулев ${ }^{1}$ Ф. И., Поспеева ${ }^{2}$ Е. В.

\section{НЕОТЕКТОНИЧЕСКАЯ СТРУКТУРА САЛАИРА (ЮГ ЗАПАДНОЙ СИБИРИ) И ЕЕ СООТНОШЕНИЕ С ДОКАЙНОЗОЙСКОЙ СИСТЕМОЙ РАЗЛОМОВ}

${ }^{1}$ Институт геологии и минералогии СО РАН им. В. С. Соболева, 630090, Новосибирск, просп. Коптюга, 3, Россия

${ }^{2}$ Институт нефтегазовой геологии и геофизики СО РАН им. А. А. Трофимука, 630090, Новосибирск, просп. Коптюга, 3, Россия

\section{Введение}

Неотектоническая активизация палеозойских и мезозойских складчатых зон явление характерное для всего Центрально-Азиатского складчатого пояса. Изучение неотектонической структуры таких зон позволяет выявить закономерности, по которым развивается процесс тектонической активизации древней структуры и определить соотношения между унаследованными и новообразованными структурными формами, что является фундаментальной проблемой тектоники. Количество и интенсивность орогенных этапов, которые претерпела та или иная складчатая область после завершения палеоокеанической стадии своего развития, во многом определяет индивидуальность геологического строения региона и степень его информативности с точки зрения решения сформулированной выше проблемы. Представленная работа посвящена морфотектоническому анализу Салаирского кряжа, расположенного на северо-западе Алтае-Саянской складчатой области (Рис. 1). Тектоническое развитие палеозойских орогенов в мезозое и кайнозое и реактивация палеозойских структур на неотектоническом этапе интенсивно изучались в Горном Алтае: ряд работ посвящен рассмотрению общих закономерностей внутриконтинентальной тектоники орогенов (Добрецов и др., 1995, Buslov et al., 2004), другие описывают результаты геоморфологических (Новиков и др., 1995, 2016, Новиков, 1996, 2002, 2015) структурно-геологических (Буслов и др., 1999, Буслов и др., 2003, Дельво и др., 1995, Dehandschutter et al., 2002) и термохронологических исследований (De Grave et al., 2007, 2008, Glorie et al., 2012, Ветров и др., 2016) процесса реактивации древних орогенов. Салаирский кряж изучен в этом отношении значительно слабее. Индивидуальные особенности каждого горного сооружения служат источником информации о той иной черте внутриконтинентальной тектонической динамики орогенов. На Горном Алтае наблюдается зрелая стадия неотектонической активизации палеозойского орогена с формированием альпийского 
рельефа, значительными амплитудами и дифференциацией тектонических движений, высокой сейсмичностью. При этом доорогенный рельеф региона в значительной степени уничтожен эрозией. Салаирский кряж представляет собой объект, где неотектоническая активизация находится в инициальной стадии. На Горном Алтае кайнозойские отложения приурочены только к отдельным межгорным котловинам, а денудационные поверхности, смещенные по новейшим разломам, выработаны в скальных породах и являются «немыми», что затрудняет определение их возраста и корреляцию. На Салаирском кряже и сопредельных равнинах широко распространены неогеновые осадки (Адаменко, 1976; Малолетко, 1972; Бабин и др., 2007), а также коры выветривания, облик которых изменяется в зависимости от возраста (Волков, Казьмин, 2007; Кулькова, Волкова, 1997; Коры..., 1979). Эти особенности позволяют коррелировать разновозрастные денудационные поверхности и служат повышению достоверности результатов структурногеоморфологического изучения неотектонических смещений. Вышесказанное определяет актуальность структурно-геоморфологических исследований Салаирского кряжа в рамках изучения внутриконтинентальной тектонической динамики орогенных зон.

Салаирский кряж - представляет собой покрытое тайгой низкогорное сооружение с плоскими водоразделами, разделяющее равнины Бийско-Барнаульской и Кузнецкой впадин. Это маловыразительное горное сооружение протяженностью около 250 км и шириной от 45 до 80 км, возвышающееся над окружающими равнинами на 100-200 м хорошо известно геологам благодаря тому, что с начала XIX века является районом интенсивной добычи россыпного золота (Щуровский, 1846), которая в незначительных объемах продолжается до настоящего времени (Росляков и др., 2001, Неволько и др., 2019). В литературе существует устойчивое мнение о формировании современной возвышенности Салаирского кряжа за счет сводового воздымания с последовательным формированием разновозрастных поверхностей выравнивания на крыльях свода при замедлениях неотектонических движений, датированных по корам выветривания, (Усов, 1935; Соколов, 1936; Сваричевская, 1965; Вдовин, 1965, Малолетко, 1972; 2008; Даргевич, Лоскутов, 2000; Калинин и др., 2006). Однако эта точка зрения может считаться устаревшей, поскольку не учитывает новые данные об изменении глобального базиса денудации в мезозойское и кайнозойское время и геохронологические данные, касающиеся неотектоники. В связи с введением в научный оборот детальных сведений об изменении уровня Мирового океана в мезозойско-кайнозойское время (Vail et al., 1977; Haq et al., 1987, 1995; Miller et al., 2011) и о времени начала главной фазы неотектонической активизации Салаира (Novikov, Sokol, 2007) для объяснения механизма формирования существующей здесь лестницы поверхностей выравнивания мы 
используем другую модель (Новиков и др., 2013; 2019). Согласно этой модели, последовательность позднемезозойских и раннекайнозойских поверхностей выравнивания следует объяснять формированием в результате поэтапного понижения базиса денудации и лишь в конце кайнозоя ее гипсометрическое положение стало изменяться в результате восходящих блоковых движений.

Для определения характера неотектонической активизации мы провели морфотектонические исследования территории Салаира. Были выявлены разломные границы и проанализированы основные морфометрические параметры выделенных блоков. Для изучения глубинной тектонической структуры региона проведено магнитотеллурическое зондирование (МТ3) территории с пересечением Салаирского кряжа двумя профилями МТЗ, а для установления степени связи границ неотектонических структур разломами палеозойского и мезозойского возраста проведено пространственное сравнение сети разломов, сформированных в докайнозойское время и на неотектоническом этапе.

\section{Геоморфология Салаирского кряжа и его обрамления}

Салаирский кряж образует юго-западное ограничение Кузнецкой впадины и представляет собой типичное низкогорье, морфологически сходное с низкогорьями Кузнецкого Алатау и Горной Шории, обрамляющих Кузнецкую впадину с востока и юга (рис. 2А). Вершинную поверхность этих низкогорий региона образует ступенчатая мелпалеогеновая поверхность выравнивания, включающая три сближенных высотных уровня, разделенных сглаженными уступами высотой 30-50 м. Верхний, наиболее древний уровень, формировавшийся в середине мела на абсолютных отметках около 300 м сохранился только на вершинах останцовых возвышенностей (монадноков), сложенных устойчивыми к денудации породами, а позднемеловой и палеогеновый, с исходными абсолютными отметками около 250 и 200 м соответственно, имеют широкое распространение и рассматриваются нами как единая ступенчатая мел-палеогеновая поверхность выравнивания. В пределах низкогорий Салаира, Кузнецкого Алатау и Горной Шории современная высота поверхности выравнивания чаще всего лежит в пределах 400600 м. Окраины этих горных сооружений возвышаются над прилегающими равнинами на 150-300 м. Однако такой разницы высот оказалось достаточно для проявления климатической зональности и на территориях горных сооружений сформировались таежные ландшафты, в то время как ландшафты равнин представляют собой лесостепь, которая в настоящее время существенно преобразована сельскохозяйственной деятельностью (рис. 2В). 
К востоку от Салаира расположена Кузнецкая котловина. От горных сооружений Салаира она отделена системой невысокимх кулисообразно расположенных в плане уступов (местное название - «тырганы»). Геоморфологическое строение котловины неоднородно. Центральная часть занята денудационной равниной (пенепленом), срезающей умеренно дислоцированные отложения верхнего палеозоя и мезозоя. В северной части пенеплен перекрыт покровом лессовидных суглинков мощностью до 30-50 м. На северо-востоке и юго-востоке дно Кузнецкой котловины образовано пенепленом, срезающим преимущественно дислоцированные раннепалеозойские породы. Высотные отметки водоразделов котловины в основном лежат в пределах 270-350 м - т.е. на неотектоническом этапе она практически не испытала вертикальных неотектонических смещений.

К юго-востоку от Салаирского кряжа расположена Ненинско-Чумышская котловина, днище которой представляет собой пластовую равнину, развитую по меловым отложениям. Высота водоразделов в пределах днища котловины 300-350 м.

K юго-западу от Салаира расположена пластовая равнина, развитая по палеогеновым и неогеновым недислоцированным песчано-глинистым отложениям и разделенная Верхнеобской флювиальной равниной на Приобское плато и БийскоЧумышскую возвышенность. Она перекрыта чехлом лессовидных суглинков мощностью 30-50, редко до 100 м. Высота водоразделов пластовой равнины 250-350 м. Верхнеобская аккумулятивная равнина сложена аллювиальными и катафлювиальными песками местами преобразованными эоловыми процессами (Зольников, 2009). Высотные отметки равнины 130-230 м.

K северо-западу от Салаирского кряжа и Кузнецкой котловины расположена Буготакско-Сокурская равнина, образованная пенепленом, выработанным по сильно дислоцированным среднепалеозойским отложениям. Она перекрыта практически сплошным чехлом лессовидных суглинков мощностью 30-50, редко до 100 м. Высота водоразделов Буготакско-Сокурской равнины обычно 250-310 м. Сходная по морфологии, высотам и покровным отложения равнина расположена между низкогорьем Салаира и Бийско-Чумышской возвышеностью. Единственным ее отличием является то, что она развита по характерным для Салаира нижнепалеозойским породам. Поэтому при морфотектоническом анализе мы рассматриваем ее как часть Салаирского мегаблока, представляющего малоамплитудное неотектоническое поднятие, окруженное территориями остающимися практически не вовлеченными в неотектоническую активизацию. 


\section{Морфотектоника Салаира}

В рельефе территории Салаира наблюдается широкий набор черт, традиционно интерпретируемых как признаки активных разломов: уступы в рельефе, имеющие прямоугольные очертания, строго прямолинейные участки долин, участки долин, имеющие резкие прямоугольные изгибы, прямолинейные контакты различных генетических типов рельефа (Ушко и др., 1967). При реконструкции неотектонической структуры Салаира проблемой является малые вертикальные амплитуды смещений на границах между блоками, которые часто меньше или соизмеримы с уступами, разделяющими разновозрастные уровни поверхностей выравнивания. Классические методы морфотектонического анализа, основанные на выделении дифференцированных межблоковых деформаций, хорошо себя проявившие в пределах областей Центральной Азии со среднегорным и высокогорным рельефом (Новиков, 2001), здесь не всегда эффективны. Высотная дифференциация рельефа в пределах Салаира невелика, и тектоногенные уступы с высотами более 100 м развиты в основном на его границах, за исключением юго-западной. В условиях слабой высотной дифференциации неотектонических блоков, при проведении их границ мы использовали анализ рисунка дренажной сети. Принципы выявления участков речной сети, связанных с зонами дробления новейших разломов сформулированы довольно давно (Zernitz, 1932) и с тех пор успешно применяются без существенных изменений (Ушко и др., 1967; Menges, 1984: Radaideh et al., 2016; Staškovanová, Minár 2016). На территории Салаирского кряжа развит угловатый тип дренажной сети, характеризующийся прямолинейными участками долин, с резкими поворотами долин на 70-120. Например, река Чумыш в истоках течет строго на юг, затем резко поворачивает на восток, затем резко на юг, затем резко на запад, затем на северо-восток и затем, перед впадением в Объ, на юго-запад. Длина прямолинейных участков долины реки Чумыш составляет от 20 до 100 км. Подобный характер долин, имеющих в плане вид набора прямолинейных участков, сочлененяющихся между собой с резкими поворотами, характерен и для остальных рек, дренирующих Салаир. Формирование такого рода дренажной сети возможно только при жестком структурном контроле. Если бы Салаир был единым сводом или наклоненным блоком, формирующаяся дренажная сеть имела бы дендровидный характер. Угловатый тип дренажный сети формируется только при хрупком разрушении верхней части литосферы, сложенной хорошо литифицированными, устойчивыми к размыву породами, при этом выработка эрозионных долин происходит по зонам дробления вдоль новейших разломов (Ушко и др., 1967; Новиков и др., 2013). 
Салаирский неотектонический мегаблок занимает несколько большую площадь чем собственно Салаирский кряж, поскольку юго-западные края слагающих его блоков закрыты покровным комплексом четвертичных лессовидных суглинков и в орографическом плане являются частью Бийско-Чумышской равнины (рис. 2). Салаирский кряж как неотектоническое горное сооружение и Салаир как раннепалеозойская геологическая структура впадина не полностью совпадают. При рассмотрении геометрических закономерностей неотектонических блоков территории мы, для большей достоверности, включили в анализ блоки, полностью или частично относящихся к одному из этих объектов. Межблоковые границы имеют разную протяженность в разных частях территории. На большей ее части более вытянутыми являются границы северо-западного простирания, а границы северо-восточного простирания образуют короткие перемычки между ними. Вблизи юго-западной границы территории ситуация меняется: неотектонические блоки увеличиваются в размерах и утрачивают вытянутость в северозападном направлении.

Салаир, в позднемеловое время и в палеогене мало отличавшийся по тектоническому режиму и морфологии земной поверхности от своего складчатого обрамления, подвергся неотектонической активизации, которая выразилась в формировании в его пределах системы новейших блоков. Совпадение позиции новейших межблоковых разломов с положением палеозойских и мезозойских разрывных нарушений происходит в основном на границах с Кузнецкой, Ненинско-Чумышской и БуготакскоСокурской равнинами. Прямолинейные участи долин, выработанные в трещиноватых зонах новейших разломов, имеют выработанный продольный профиль и плоское днище шириной от 300 до 500 м. Морфология долин слабо кореллирует с порядком водотока и часто не изменяется после впадения притоков. Судя по тому, что в прирусловых обнажениях трещиноватость проявлена незначительно мы предполагаем, что зоны трещиноватости полностью освоены элементами гидросети в ходе формирования системы эрозионных долин территории и ширина днищ долин примерно соответствует ширине зон трещиноватости новейших разломов. За исключением пограничных неотектонических структур, где вертикальные амплитуды составляют местами от 100 до 200 м, смещения по большинству новейших разломов незначительны. Достоверных данных о существенных горизонтальных смещениях нет, но исходя из того, что для географически близкой территории Алтая, находящейся в сходных условиях сжатия, горизонтальные амплитуды смещения превышают вертикальные в 5-10 раз (Новиков, 2001; Новиков и др., 2004), их можно ориентировочно оценить в 500-2000 м для пограничных, и 100-500 м для остальных структур. Судя по морфологии границы между Салаиром и Кузбассом, 
представляющей собой систему кулисообразно расположенных уступов и общее сжатие территории по оси север-юг, можно предположить для этой границы правосдвиговый характер в сочетании со взбросом.

\section{Методика структурно-геоморфологического анализа}

При выделении неотектонических блоков методом морфоструктурного анализа мы придерживались основных принципов, предложенных Ю.А. Мещеряковым (1965): принципом соразмерности структурных и геоморфологических элементов и принципом сопоставимости элементов рельефа и тектоники по возрасту. Ю.Г. Симонов (1972) справедливо называл эти принципы основой структурно-геоморфологического анализа. Для сопоставления отдельных структурных и орографических элементов следует установить их соизмеримость, пространственное и временное соответствие. Система современных долин Салаира и система новейших разрывных нарушений генетически и пространственно взаимосвязаны. Они оформились в поздненеоген-раннечетвертичное время. Следовательно, анализ дренажной сети региона позволяет достоверно реконструировать систему его новейших разрывных нарушений. Расположение долин в пространстве показывает, что разрывные структуры образуют регулярную систему разломов. Ранее на большом фактическом материале было доказано, что линейные размеры неотектонических блоков соотносятся как 10:7:5. Коэффициенты удлиненности блоков в плане могут быть 10:7 = 7:5 = 1,4 или 10:5 = 2. [Симонов, 2003].

Задача выявления блоковых структур с помощью трехмерных моделей рельефа состоит в том, чтобы, используя эту зависимость и зная высотные уровни отдельных участков поверхности, восстановить по соотношению этих уровней размещение рельефообразующих разломов, знак перемещения и его амплитуду. Первой операцией при выделении блоков тектонического рельефа, испытавших взаимные перемещения в вертикальном направлении, является установление минимальной разницы высот, достаточной для отнесения двух соседних участков к “разновысотным” блокам. Установление этой величины имеет большое значение для последующего анализа: если разница будет больше, чем нужно, то блоки, соответствующие масштабу исследований, не будут выявлены и площадь окажется разделенной лишь на незначительное количество частей; если же разница будет мала, количество блоков будет столь велико, что увязать движения, формирующие их высоты, будет невозможно. Выбирая минимальную учитываемую разницу высот, нужно учитывать разброс высот в пределах исследуемой территории. Оптимальный шаг составляет 1/10 разброса высот за вычетом единичных эксцессов (Симонов, 2003). Так, в пределах Салаира при общем разбросе 
гипсометрических отметок менее 300 м значимыми и требующими генетической интерпретации являются различия в высотах смежных блоков 30 м.

Поверхность каждого блока, как правило, не является ровной плоскостью даже приближенно, а отличается той или иной степенью неровности. На данной стадии анализа денудационные изменения тектонического рельефа игнорируются, и всей поверхности блока условно приписывается наивысшая отметка плоского водораздела в центре участка. Иными словами, восстанавливаются первичные тектонические формы рельефа. Проведенный анализ распределения максимальных отметок водоразделов выделенных блоков показал, что в подавляющем большинстве случаев разница высот смежных блоков, разделенных прямолинейным участком долин составляет более 50 м, что подтверждает интерпретацию таких участков как выработанных по зонам дробления вдоль блокораздельных неотектонических разломов.

\section{Результаты структурно-геоморфологического анализа}

В ходе морфоструктурного анализа территории Салаира выделено 94 неотектонических блока. Высота их водораздельных поверхностей от 305 до 559 м, в среднем она составляет 432 м (рис. 3). Распределение абсолютных высот позднемелового пенеплена отдельных неотектонических блоков образует пять групп с шагом около 50 м, которые настолько мало различается по высоте, что при соседстве блоков из смежных групп, граница между ними с учетом исходной ступенчатости на водораздельной реперной поверхности с тем же шагом не может интерпретироваться как тектоногенный уступ. При соседстве блоков, более существенно отличающихся высотами вершинной поверхности, как это имеет место на трех из четырех границах Салаирского мегаблока, тектоногенные уступы достаточно хорошо выражены в рельефе.

Длина неотектонических блоков составляет обычно от 5 до 46 км. В среднем по выборке она составляет 22 км, но ее распределение имеет два максимума 15 и 38 км. Блоки с меньшей длиной тяготеют к северо-восточной части Салаира. Ширина неотектонических блоков Салаира лежит в диапазоне от 4 до 29 км. В среднем она составляет около 10 км, но распределение также имеет два максимума 8 и 25 км. Более широкие блоки образуют юго-западную часть Салаирского кряжа. Около 65\% от общего числа блоков имеют соотношение длины к ширине в пределах 1,1-1,8, что соответствует статистическим закономерностям для большинства территорий. Остальные блоки имеют коэффициент удлинения от 2 до 4, что связано с масштабом исследования. Считается что такое частотное распределение линейных размеров неотектонических блоков подтверждает достоверность их выделения (Симонов, 1972, 2003). 
Положение нижней границы неотектонических блоков, слагающих территорию Салаира, позволяют понять данные магнитотеллурического зондирования о глубинном строении территории. Такого рода исследования уже показали свою эффективность в других районах Алтае-Саянской складчатой области (Неведрова и др., 2011; Поспеева и др., 2014). В 2019 году два профиля магнитотеллурического зондирования (МТЗ) были проведены нами через территорию Салаирского кряжа с заходом на прилегающие равнины. Работы по магнитотеллурическому зондированию выполнены на основе новейших технологий V5 System - 2000 тремя комплектами аппаратуры «MTU-5» компании «Phoenix Geophysics» (Канада). Более подробное описание методики ранее приводилось в нашей статье (Новиков, Поспеева, 2017).

Наиболее интересным результатом проведенного магнитотеллурического зондирования было выявление под территорией Салаира плоскости срыва по которой он надвинут на Кузнецкую впадину. Наличие субгоризонтального внутрикорового проводящего слоя на профиле А-В интерпретируется нами как зона разделительного срыва в основании Салаирской неотектонической аллохтонной пластины. Повышенная проводимость зоны связана с тектонической дезинтеграцией и флюидонасыщеностью зоны разделительного срыва, кроме того, нельзя исключить присутствия на глубине фрагментов тектонически перекрытого верхнепалеозойского осадочного чехла Кузнецкого прогиба. На профиле C-D, приблизительно на тех же глубинах, (около 10 км) происходит перегиб изолиний удельного сопротивления, который может быть интерпретирован как примыкание фронтального взброса, ограничивающего надвиговую пластину к субгоризонатальному разделительному срыву (Жимулев и др., 2021).

Наличие на профилях МТЗ структуры интерпретируемой как зона дробления, связанная с горизонтальным срывом на глубинах порядка 10 км, выходящим на поверхность не в основании тектоногенного уступа, ограничивающего Салаирский мегаблок с северо-востока, а на невыраженной в современном рельефе границе между салаирскими и кузнецкими структурами, позволяет считать эту зону унаследованной от мезозойского этапа активизации. На неотектоническом этапе она играет роль нижней разломной границей неотектонических блоков Салаирского кряжа, которые образуются в результате хрупкого разрушения пластины Салаирского мегаблока при его горизонтальном смещении в ходе регионального сжатия. Уменьшение толщины надвиговой пластины по направлению к Кузнецкой впадине хорошо согласуется в наблюдаемом в уменьшении плановых размеров неотектонических блоков в том же направлении. Наши взгляды относительно природы неотектонической активизации принципиально расходятся со взглядами Ю.Г.Симонова, который не признавал в качестве ее источника коллизионные 
события на окраинах континентов, но выявленные им эмпирические закономерности в размерности блоков земной коры при хрупком разрушении верхней ее части получили подтверждение при изучении территории Салаирского кряжа.

\section{Докайнозойская сеть разломов Салаира и ее соотношение с системой}

\section{новейшей блоковой делимости}

Раннепалеозойское складчато-покровное сооружение Салаира сложено преимущественно вулканогенными, карбонатными и терригенными породами, сильно дислоцированными, но неметаморфизованными или метаморфизованными до зеленосланцевой фации. (Фомичев, Алексеева 1961; Бабин и др., 2007). Только в южной части Салаира встречаются высокометаморфизованные породы (Шокальский и др., 2000). В тектонической истории Салаирского складчато-покровного сооружения выделяется несколько орогенических событий. Причиной первого орогенеза послужила раннеордовикская аккреция островодужных комплексов, к Сибирскому континенту. Второе, позднепермское орогенное событие, связано с закрытием Палеоазиатского океана. Данное событие привело к формированию гранитоидных интрузий и складчато-покровной структуры Салаира. Третий, мезозойский, орогенез, проявившийся в накоплении грубообломочных отложений сопряженных с Салаиром грабен-синклиналей (Жимулев и др., 2021) связывают с закрытием Палеотетиса (Yin, Harrison, 2000; Jolivet et al., 2001) или Монголо-Охотского палеоокеана (Cogné et al., 2005; Донская и др., 2012). Четвертая позднекайнозойская активизация, свидетельством которой служит выраженное в современном рельефе неотектоническое поднятие Салаирского кряжа традиционно связывают с Индо-Евразийской коллизией (Molnar, Tapponnier, 1975). Между орогенными событиями территория переживала длительные периоды тектонического покоя в ходе которых происходила нивелировка горного рельефа процессами денудации с формированием поверхностей выравнивания.

Палеозойская структура Салаира имеет чешуйчато-надвиговое строение и включает серию смятых в складки тектонических пластин (Бабин и др., 2007, Токарев и др., 2002, Токарев и др., 2019 а, б, Dobretsov et al., 2004). Выходы тектонических пластин на земную поверхность имеют вид узких линейных зон, шириной 1-10 км, при протяженности до нескольких десятков километров. В плане эти зоны изогнуты конформно границам Салаирского аллохтона. Тектонические пластины сложены вулканическими породами, вулканомиктовым флишем, известняками и породами офиолитовой ассоциации. Время формирования этой породной ассоциации охватывает все отделы кембрия и ранний ордовик. Согласно существующим представлениям, большая 
часть кембрийских пород Салаира формировалась в обстановке океанической островной дуги, в составе Аламбайской офиолитовой зоны встречаются базальты, отвечающие по составу внутриплитным образованиям и являющиеся фрагментами океанических островов или плато (Бабин и др., 2007, Берзин, Кунгурцев, 1996, Зоненшайн и др., 1990, Токарев и др., 2002, Токарев и др., 2019, Шокальский и др., 2000, Dobretsov et al., 2004).

В триасовое и раннеюрское время Салаир продолжил надвигание на Кузнецкую впадину, выполненную позднепалеозойской угленосной молассой, которая на фронте надвига была собрана в складки, осложненные системой субпараллельных дугообразноизогнутых взбросов, в плане повторяющих форму надвиговых тектонических пластин Салаира. На северо-западе северный фланг Салаирской структурной дуги и Кузнецкая впадина тектонически перекрыты аллохтоном Колывань-Томской складчатой зоны (Матвеевская, 1969; Юзвицкий, 1966; Zhimulev et al., 2020).

Таким образом, в пределах рассматриваемой территории наблюдается три группы докайнозойских разломов: разломы Салаирского складчато-покровного блока, разломы Колывань-Томской складчатой зоны, разломы собранной в складки юго-западной окраины Кузнецкой впадины (рис. 4). Характер разломов этих трех групп принципиально различается по возрасту и морфологии.

Разломы Колывань-Томской складчатой зоны имеют северо-восточное простирание. Они осложняют систему линейных складок аналогичного простирания в который собраны морские терригенные отложения среднего-верхнего девона и раннегосреднего карбона. Протяженность разломов нередко превышает 50 км. Расположены они субпараллельно через 5-10- км. Это преимущественно взбросы и надвиги с падением сместителей на северо-запад под углами от 20 до $50^{\circ}$ (Сотников и др., 1999). Разломы юго-западной окраины Кузнецкой впадины представляют собой субпараллельную систему дугообразно изогнутых взбросов с падением сместителей на юго-запад под углами от 50 до 70. Протяженность разломов составляет до 200 км. Расстояние между ними 5-10 км.

Главные разломы Салаирского кряжа, ограничивающие тектонические пластины различного состава, имеют дугообразную форму, изгибаясь согласно общему простиранию Салаирских структур: на севере они имеют юго-западное простирание, в центральной части - северо-западное, и вновь юго-западное на юге Салаира. Разломы субпараллельны. Расстояние между ними примерно 10-20 км, а протяженность отдельных разломов составляет обычно 100-200 км.

Большая часть разломов смещает девонские и раннекарбоновые породы, образующие деформированный чехол Салаирского раннепалеозойского блока, что, вероятно, объясняется реактивацией раннепалеозойских разломов в позднем палеозое. В 
то же время, породы нижнего, кембрийско-раннеордовикского структурного этажа, отличаются значительно большей степенью деформаций, по сравнению со всеми вышележащими породами, включая карбонатно-терригенные отложения силурийского возраста.

Фронтальные взбросы Салаирского блока по которым он надвинут на Кузнецкий прогиб смещают пермские отложения балахонской серии, Последняя, учитывая значительный градиент мощностей может рассматриваться как синтектоническая толща, а присалаирская зона Кузнецкого прогиба, где мощность осадочного выполнения максимальна (Лавренов и др., 2018, Угольная база, 2003) как Присалаирский форланд. Пермские отложения в этой зоне нарушены дугообразно-изогнутыми взбросами, в плане повторяющими форму надвиговых тектонических пластин Салаира.

Еще один импульс реактивации разломной структуры имеет послесреднееюрский возраст, на что указывают следующие факты: Нижне- и среднеюрские отложения залегают на пермских часто без видимого структурного несогласия и образуют с ними единые складчатые структуры, постсреднеюрского возраста. По некоторым из чешуйчатых надвигов Присалаирской зоны палеозойские породы надвинуты на мульды, сложенные нижнеюрскими отложениями (Токарев и др., 2019, Лавренов и др., 2018).

Южная граница Салаира, где раннепалеозойские породы, взброшены на нижнемеловые отложения илекской свиты, выполняющие Ненинско-Чумышскую тектоническую депрессию, представляют собой пример позднемезозойской разломной тектоники. Разлом, разграничивающий структуры Салаира и Ненинско-Чумышской впадины известен как Баркинский взбросо-надвиг (Токарев и др., 2019). Бурением установлено тектоническое перекрытие девонско-раннекарбоновыми породами меловых осадков илекской свиты. Вдоль плоскости разлома в глинах илекской свиты наблюдаются зеркала скольжения. Взбросо-надвиг характеризуется крутым падением сместителя на северо-запад, вертикальной амплитудой более 500 м. Баркинский всбросо-надвиг прослеживается на 130 км. Отсутствие меловых отложений в других частях Салаира затрудняет выявление разломов мелового возраста, но можно предположить, что такая крупная тектоническая структура, сопровождалась тектоническими движениями по другим разломам.

По сравнению с докайнозойскими разломами, неотектонические разрывные нарушения отличаются значительно меньшими амплитудами смещений и протяженностью. Их протяженность редко превышает 40 км, составляя обычно 10-15 км. Вертикальные амплитуды смещений достигают первых сотен метров только на внешних границах Салаира, составляя преимущественно первые десятки метров. Наиболее 
крупные нарушения на внешних границах Салаира более всего близки по масштабам к разломам более древнего возраста. Все они имеют унаследованный характер избирательно обновляя отдельные отрезки докайнозойских разломов. В пределах самого Салаира степень унаследованности минимальна и неотектонические межблоковые границы являются в абсолютном большинстве новообразованными. Таким образом, Салаирский палеозойский складчато-покровный комплекс в неотектоническом плане ведет себя как единый блок, тектоническое расчленение которого находится на самой начальной стадии.

\section{Обсуждение результатов}

Судя по наличию вокруг Салаирского кряжа системы юрских впадин, выполненных угленосной грубообломочной молассой (Боголепов, 1967, 1985; Вдовин, Малолетко, 1969; Башарина, 1975) в среднемезозойское время на территории Салаира существовал достаточно высокий горный хребет. Неотектонические движения Салаира являются унаследованными, но их вертикальная составляющая существенно меньше чем в предшествующие эпохи. В ходе неотектонической активизации вокруг низкогорий Салаира и Кузнецкого Алатау нигде не были сформированы грубообломочные молассы, подобные наблюдающимся в юрских впадинах вокруг этих горных сооружений. Отложения подобного типа формируются в позднем кайнозое во впадинах южной части Горного Алтая, во впадинах Монгольского Алтая и на его периферии, где высоты современных горных сооружений превышают 2-3 км. Это служит основанием для заключения, что неотектонические движения Салаира происходят с примерно в 10 раз меньшей вертикальной составляющей, чем в ходе юрского орогенеза (до 200-300 м в четвертичное время и примерно 2000-3000 м в юрское).

Существенное наследование неотектоническими структурами кинематики и пространственной позиции докайнозойских тектонических нарушений на северовосточной и юго-восточной границах Салаира с Кузнецкой впадиной создает иллюзию решающего влиянии структур докайнозойского основания на заложение новейших разломов на всей территории неотектонического поднятия Салаира. Однако проведенный нами сравнительный анализ пространственной позиции древней и современной сети разломов территории показал, что это не так. Даже древний структурный шов, разделяющий кузбасские и салаирские структуры, в своей северной половине не находит отражение в сети новейших разломов. В пределах самого Салаира протяженность унаследованных структур незначительна. Формирование позднепалеозойской системы разломов происходило при сжатии с северо-запада и юго-запада в условиях, когда земная кора в пределах территории еще не была достаточно консолидирована и ее верхние отделы 
имели возможность сминаться в напряженные складки, в том числе, ассоциирующие с тектоническими покровами. Судя по рисунку кайнозойских разломов неотектоническая активизация территории Салаира происходила в результате сжатия по субмеридиональному направлению в условиях достаточно консолидированной коры, что привело к хрупкому дроблению верхних ее отделов на блоки и совместному их смещению в северном направлении. Неотектоническая граница Салаирского кряжа с Кузнецкой котловиной представляет собой кулисообразную систему новейших взбросов, наследующих докайнозойский тырганский взброс только в южной его части. На севере новейшие разломы отсекают полосы шириной по 15-30 км от складчатых сооружений Салаира, оставляя их в пределах новейшей межгорной впадины.

Амплитуды вертикальных перемещений докайнозойских разломов можно определить по разнице в стратиграфическом положении комплексов пород, расположенных по разные стороны разломной границы. На границах Салаира они составляют обычно около 2 км. Например, на северо-западной границе Салаира в районе Гурьевска вулканогенно-осадочные породы краснянской свиты нижнего ордовика ( $\left.\mathrm{O}_{1} \mathrm{ks}\right)$ взброшены на формировавшиеся в одном с ними бассейне вулканогенно-осадочные породы нерасчлененных керлегешской и сафоновской свит $\left(\mathrm{D}_{2} \mathrm{kl}+\mathrm{sf}\right)$ с выпадением из разделяющих их в стратиграфической последовательности отложений среднего-верхнего ордовика, силура и нижнего девона суммарной мощностью более 2000 м. (Токарев и др., 2002). В районе Прокопьевска девонские осадочно-эффузивные породы живета $\left(\mathrm{D}_{2} \mathrm{gv}\right)$ надвинуты на угленосные молассы верхнебалахонской подсерии $\left(\mathrm{P}_{1} \mathrm{bl}_{2}\right)$ с выпадение из разреза отложений карбона мощностью более 1700 м (Токарев и др., 2019).

Неотектоническая активизация Салаира без сомнения является удаленным эффектом Индо-Евразийской коллизии. Рассматриваемый регион находится в области динамического воздействия коллизии на максимальном удалении от коллизионной зоны и интенсивность неотектонических процессов там относительно мала. Прямым подтверждением наличия горизонтального регионального сжатия в регионе можно считать GPS данные о сближении Джунгарской и Западно-Сибирской плит со скоростью 2-4 мм/год (Yang et al., 2005; Calais et al., 2006; Vergnolle et al., 2007) и сближении территории Алтая с Западно-Сибирской плитой со скоростью около 1 мм/год (Тимофеев и др., 2017). Соотношение амплитуд вертикальных и горизонтальных движений на неотектоническом этапе для Алтае-Саянской горной области давно установлены (Новиков, 2001). Они составляют приблизительно 1 к 10 и вычисляются по соотношению амплитуд вертикальных смещений блоков, составляющих до 2000-4000 м (Новиков, 1996, 2001), и амплитуд горизонтальных смещений за кайнозойское время, составляющих до 20- 
40 км (Shi et al., 1984; Новиков, 1996; Klinger et al., 2011). Судя по абсолютным датировкам коррелятных пирометаморфических пород основная фаза неотектонических движений Салаирского мегаблока происходила 1,8 + 0,2 млн. лет назад (Novikov, Sokol, 2007). Амплитуда вертикального подъема наиболее возвышенной части Салаирского мегаблока судя по высоте ограничивающих ее с севера и северо-востока тектоногенных уступов составляет около 200 м, а время активизации около 2 млн. лет. Соответственно среднюю скорость воздымания мегаблока можно оценить в 0,1 мм/год. Эта величина хорошо коррелирует с данными о смещении южного обрамления мегаблока в северном направлении со скоростью около 1 мм/год (Тимофеев и др., 2017), составляя 1/10 от нее.

Анализ распределения размеров и абсолютных высот вершинных поверхностей выделенных блоков. показывает, что новейшие тектонические нарушения Салаира представляют собой зоны трещиноватости, использованные гидросетью, на что указывает ярко-выраженный угловатый рисунок дренажной системы. Вертикальные смещения по зонам трещиноватости не всегда присутствуют в новейшей структуре, как правило, амплитуды их существенно менее 100 м. При мелкомасштабных исследованиях Салаир на неотектоническом этапе может рассматриваться как как единый мегаблок размером примерно 80 на 250 км. Дифференцированные движения хорошо проявлены на южной, северной и восточной границах мегаблока, где их вертикальная амплитуда достигает 200 м. Наряду с элементами унаследованности кинематики на северо-восточной границы, на юго-восточной границе с Ненинско - Чумышской впадиной наблюдается инверсия кинематики. В юрское время Ненинско-Чумышская впадины формировалась в условиях растяжения и имела сбросовые границы, но на новейшем этапе движения по пограничным разломам приобрели характер взбросов, что хорошо видно по зеркалам скольжения при надвигании палеозойских пород Салаира на меловые породы верхнего структурного этажа впадины (Бычков, 1990). Толщина Салаирского мегаблока по данным магнитотеллурического зондирования увеличивается с востока на запад с 5 до 15 км в северной части блока и 10 до 20 км в южной его части. Снизу он ограничен зоной низких сопротивлений, которая интерпретируется как флюидонасыщенная область в зоне субгоризонтального разделительного срыва.

Характер неотектонической блоковой делимости Салаира указывает на наличие регионального субгоризонтального сжатия в субмеридиональном направлении. Об этом же свидетельствуют горизонтальные напряжения в выработках, превышающие литостатическое давление кровли, зарегистрированные в Кузбассе и Горной Шории (Бгатов, Лукашев, 1982). Региональное сжатие проявляется также в виде наведенной сейсмичности, возникающей как результат частичной разрядки напряжения (Еманов и 
др., 2009; Овсюченко и др., 2010; Брыксин, Селезнев, 2012). Взбросовые механизмы очагов землетрясений на границе Кузбасса и Салаира свидетельствуют о надвигании последнего на Кузнецкую котловину (Еманов и др., 2016). В этом неотектоническая активизация наследует, хотя и в принципиально меньших масштабах позднеюрскораннемеловую, когда отложения присалаирской части Кузнецкой впадины были сжаты в узкую систему складок, осложненную взбросами, что привело к поперечному укорочению бассейна примерно на 30\% (Угольная база..., 2003).

Анализ линейных размеров выделенных неотектонических блоков в плане показывает, что они закономерно изменяются. Блоки с меньшими линейными размерами тяготеют к северо-восточной периферии Салаирского мегаблока, где его толщина уменьшается, а наиболее крупные неотектонические блоки слагают юго-западную часть мегаблока, где его толщина больше и достигает 15-20 км.

На профилях магнитотеллурического зондирования в виде наклонной зоны повышенной проводимости хорошо видны выходы на поверхность взброса, ограничивающего Салаирский мегаблок с северо-востока (пункты МТ3 №32 на профиле AB и № 7 на профиле CD). На профиле АВ также отчетливо видна полого погружающаяся к юго-западу зона повышенной проводимости, соответствующая нижней границе Салаирского мегаблока по которой происходит его надвигание в северо-восточном направлении. На профиле CD она имеет несколько больший наклон и на уровне пункта МТЗ № 9 выходит за поле разреза и, судя по градиенту изменения проводимости залегает на отметках ниже 20000 м и предположительно занимает горизонтальное положение на глубине около 25 км. Вдоль юго-западной границы Салаирского кряжа на профилях МТЗ отчетливо видна субвертикальная зона повышенной проводимости, отделяющая северовосточную часть Салаирского мегаблока с низкогорным рельефом от юго-западной его части с равнинным рельефом. Мы полагаем что в тектоническом отношении она соответствует зоне растяжения, сформировавшейся в Салаирском мегаблоке в ходе его надвигания на Кузнецкую впадину. Таким образом и юго-западная граница Салаирского кряжа, не выраженная в рельефе уступом, образована не пологим погружение поверхности мегаблока под чехол Бийско-Барнаульской впадины, а имеет разломную природу.

\section{Выводы}

Проблема унаследованного развития геологических структур при активизациях входит в число фундаментальных проблем тектоники континентов. Почему одни части складчатой области сохраняют монолитность, в течении нескольких тектонических циклов, а другие распадаются на мозаику тектонических блоков, почему одни участки 
земной поверхности испытывают длительную тенденцию к воздыманию, а другие к погружению, почему в одних случаях структурный рисунок определяется узкими надвиговыми пластинами, а в других субизометричными блоками - эти и многие другие вопросы, неизменно возникают при изучении тектонической истории орогенов.

Проведенная нами работа на территории Салаирского мегаблока, выраженного в рельефе в виде низкогорного Салаирского кряжа, по сопоставлению докайнозойских разрывных нарушений, выделяемых по геологическим данным и неотектонических разрывных нарушений, выявляемых при анализе гидросети, позволила выявить следующие закономерности.

При тектонических активизациях неизменно происходит реактивация крупных, региональных разломов, формирующих общий структурный каркас складчатой области. В рассмотренном случае, это серия дугообразных разломов, очерчивающих структурную дугу Салаира и отделяющих Салаирскую аллохтонную пластину от смежных тектонических зон. Эти разломы, сформированные в позднем палеозое, неоднократно реактивировались в мезозое и испытывают активизацию на неотектоническом этапе. Внутри же Салаирской аллохтонной пластины преобладает хрупкое разрушение, по сети малоамплитудных разрывов, секущих линейные контакты палеозойских надвиговых пластин. Структурный рисунок внутренних частей Салаира подобен сети трещин такыра, что свидетельствует о внутренней однородности Салаирской пластины.

Размерность Салаирского мегаблока в плане аналогична большинству новейших структур Алтае-Саянской горной области (Новиков, 2001). Отличительной особенностью является малая амплитуда вертикального смещения на неотектоническом этапе. Для мегаблока характерна высокая степень унаследованности пространственного положения от юрского структурного плана. Формирование неотектонических блоков, слагающих Салаирский мегаблок, не связано с его докайнозойскими структурами. Данные о глубинном строении, полученные при пересечении Салаира профилями магнитотеллурического зондирования представляют существенный интерес в силу того, что в горных областях крайне редко удается получить данные о нижних границах неотектонических блоков. Установленная связь толщины Салаирского мегаблока с размерами в плане неотектонических блоков, образующихся при его разрушении, подтверждают выводы Ю. Г. Симонова (1965) об устойчивом характере взаимосвязи трех измерений неотектонических блоков, образующихся при хрупком разрушении верхней части литосферы. 
Исследования выполнены при финансовой поддержке РФФИ и правительства Новосибирской области, проект 19-45-540001, базового проекта ИГМ СО РАН и базового проекта ИНГГ СО РАН.

\section{Список литературы}

Адаменко О. М. Предалтайская впадина и проблемы формирования предгорных опусканий. - Новосибирск, 1976, 184 с.

Бабин Г.А., Гусев Н.И., Юрьев А.А., Уваров А. Н., Дубский В.С., Черных А.И., Щигрев А.Ф., Чусовитина Г.Д., Кораблева Т.В., Косякова Л.Н., Ляпунов И.А., Митрохин Д.В., Бычков А.И., Некипелый В.Л., Савина Ж.Н., Егоров А.С., Шор Г.М., Алексеенко В.Д., Булычев А.В., Радюкевич Н.М., Николаева Л.С., Богомолов В.П., Шипов Р.В., Суслова С.В., Сазонов В. А., Юрьева В.В., Хлебникова Т.В., Кондрашова А.К., Тереда Н.Ф. Государственная геологическая карта Российской федерации. Масштаб1:1 000000 (третье поколение). Серия Алтае-Саянская. Лист N-45 Новокузнецк. Объяснительная записка. - СПб.: Картографическая фабрика ВСЕГЕИ, 2007. - 665 с.

Бгатов А.П., Лукашов А.А. Анализ блоковых морфоструктур Горной Шории в связи с решением вопросов глубинной инженерной геологии // Вестник Московского Университета. Серия 5. География. № 1. - 1982. - С. 44-48.

Берзин Н.А., Кунгурцев Л.В. Геодинамическая интерпретация геологических комплексов Алтае-Саянской области // Геология и геофизика. 1996. Т. 37. № 1. С. 63-81.

Брыксин А.А., Селезнев В.С. Влияние техногенных факторов на сейсмичность районов Кузбасса и озера Байкал // Геология и геофизика, 2012. - № 3, Т.53. - С. 399-405.

Буслов М. М., Зыкин В. С., Новиков, И. С. Дельво Д. Структурные и геодинамические особенности формирования Чуйской межгорной впадины Горного Алтая в кайнозое // Геология и геофизика. 1999. т. 40. № 12 С. 1720-1734.

Буслов М.М., Ватанабе Т., Смирнова Л.В., Фудживара И., Ивата К., Де Граве И., Семаков Н.Н., Травин А.В., Кирьянова А.П., Кох Д.А. Роль сдвигов в позднепалеозойско-раннемезозойской тектонике и геодинамике Алтае-Саянской и Восточно-Казахстанской складчатых областей // Геология и геофизика. 2003. T. 44, № 1-2. C. $49-75$.

Бычков А. И. Отчет Кузбасской партии о результатах геологического доизучения и съёмки масштаба 1: 50000 территории листов N-45-90-Б,Г; N-45-91-А, Б, В, Г; N-45-92А,Б; N-45-93-А. 1976-1989. Кемеровский филиал ФБУ «ТФГИ по СФО», 1990, № 20834 
Вдовин В.В., Малолетко А.М. Салаирский кряж // История развития рельефа Сибири и Дальнего востока. Алтае-Саянская горная область. - М.: Наука, 1969. - С.121156.

Ветров Е.В., Буслов М.М., И. Де Граве. Эволюция тектонических событий и рельефа юго-восточной части Горного Алтая в позднем мезозое-кайнозое по данным трековой термохронологии // Геология и геофизика. 2016. т.57. №1. С.125-142

Волков И.А., Казьмин С.П. Палеоценовая кора выветривания как важнейший хронологический репер в геологии Западной Сибири // Вестник ВГУ. Серия: Геология. 2007, № 2, 221-223 c.

Даргевич В.А., Лоскутов Ю.И. Методические рекомендации по составлению прогнозно-минерагенических карт на ильменит-цирконовые россыпи (на примере Сибири). - Новосибирск: СННИГГиМС, 2000. - 88с.

Дельво Д., Тениссен К., Ван-дер-Мейер Р., Берзин Н. А. Динамика формирования и палеостресс при образовании Чуйско-Курайской депрессии Горного Алтая: тектонический и климатический контроль //Геология и геофизика. 1995. т. 36. № 10. С. 3151

Добрецов Н.Л., Берзин Н.А., Буслов М.М., Ермиков В.Д. Общие проблемы эволюции Алтайского региона и взаимоотношения между строением фундамента и развитием неотектонической структуры //Геология и геофизика. 1995. № 10. С. 5-19

Донская Т.В., Гладкочуб Д.П., Мазукабзов А.М., де Ваэле Б., Пресняков С.Л. Позднетриасовая катаевская вулканоплутоническая ассоциация Западного Забайкалья фрагмент активной континентальной окраины Монголо-Охотского океана // Геология и геофизика, 2012, № 1, Т 53, С. 30-49.

Еманов А.Ф., Еманов А.А., Лескова Е.В., Фатеев А.В., Семин А.Ю. Сейсмические активизации при разработке угля в Кузбассе // Физическая мезомеханика. 2009. - T. 12, № 1. - С. 37-43.

Еманов А.Ф., Еманов А.А., Фатеев А.В., Лескова Е.В. Техногенное Бачатское землетрясение 18.06.2013 г. (ML=6.1) в Кузбассе - сильнейшее в мире при добыче твердых полезных ископаемых // Вопросы инженерной сейсмологии. - 2016. - Т. 43, № 4. - С. 3460.

Жимулев Ф. И., Ветров Е. В., Новиков И. С., Ван Ранст Г., Начтергаеле С., Докашенко С. А., Де Граве Й. Мезозойский внутриконтинентальный орогенез в тектонической истории Колывань-Томской складчатой зоны, синтез геологических данных и результатов трекового анализа апатита // Геология и геофизика, 2021 (в печати) 
Жимулев Ф.И., Поспеева Е.В., Новиков И.С., Потапов В.В. Глубинное строение Салаирского складчато-покровного сооружения (северо-запад Центрально-Азиатского складчатого пояса) по данным магнитотеллурического зондирования |// Геодинамика и тектонофизика. - 2021 (в печати)

Зольников И.Д. Гляциально обусловленные суперпаводки неоплейстоцена Горного Алтая и их связь с историей формирования отложений и рельефа Западно-Сибирской равнины // Бюллетень комиссии по изучению четвертичного периода, №69. - М.: ГЕОС, 2009. - C.58-70.

Зоненшайн Л.П., Кузьмин М.И., Натапов Л.М. Тектоника литосферных плит территории СССР. - М.: Недра, - 1990, Т. 1, - 325 с., Т.2, - 334 с.

Калинин Ю.А., Росляков Н.А., Прудников С.Г. Золотоносные коры выветривания юга Сибири. - Новосибирск: Академическое изд-во «Гео», 2006. - 339 с.

Коры выветривания Сибири. Формации коры выветривания Западно-Сибирской плиты и Алтае-Саянской складчатой области / Ред. Казаринов В. П. М., Недра, книга 1, 1979. - 221 c.

Кузнецов Ю.Я., Рихтер В.Г., Троцюк В.Я., Ушко К.А. Значение, теоретические основы и методика структурно-геоморфологических исследований // Структурногеоморфологические исследования при изучении нефтегазоносных бассейнов. - Л.: Изд-во Недра, Ленинградское отделение, 1967. - 234 с.

Кулькова И. А., Волкова В. С. Ландшафты и климаты Западной Сибири в палеогене и неогене // Геология и геофизика, 1997, т.38, №3, 581-595 с.

Лавренов П.Ф., Снежко Б.А., Щигрев А. Ф., Шелеметева Н. В., Филиппова Н. Е. Государственная геологическая карта Российской Федерации. Масштаб 1:200000. Издание второе. Серия Кузбасская. Лист N-45-XV (Ленинск-Кузнецкий). Объяснительная записка. М.: Московский филиал ВСЕГЕИ, 2018. 115с.

Малолетко А.М. Палеогеография предалтайской части Западной Сибири в мезозое и кайнозое. - Томск: Изд-во Томского ун-та, 1972. - 227 с.

Малолетко А.М. Эволюция речных систем Западной Сибири в мезозое и кайнозое. - Томск: Изд-во Томского ун-та, 2008. 288 с.

Матвеевская А.Л. Герцинские прогибы Обь-Зайсанской геосинклинальной системы и ее обрамления. М. Наука, 1969. 286 с.

Мещеряков Ю.А. Структурная геоморфология равнинных стран. М.: Наука, 1965. 277 c. 
Неведрова Н.Н., Поспеева Е.В., Санчаa А.М. Интерпретация данных комплексных электромагнитных методов в сейсмоактивных районах (на примере Чуйской впадины Горного Алтая) // Физика Земли, 2011. - № 11. - С. 63-75.

Неволько П.А., Колпаков В.В., Нестеренко Г.В., Фоминых П.А. Самородное золото аллювиальных россыпей северо-западного Салаира: состав, типы и минеральные микровключения // Геология и геофизика, 2019. Т. 60. - № 1. - С. 79-100.

Новиков И. С., Мистрюков А. А., Трефуа Ф. Геоморфологическое строение района Чуйской межгорной впадины (Горный Алтай) //Геология и геофизика. 1995. т. 36. № 10. C. $64-74$

Новиков И.С. Высоцкий Е.М., Агатова А.Р. Геолого-геоморфологические свидетельства позднекайнозойских обстановок сжатия, сдвига и растяжения в пределах Горного Алтая // Геология и геофизика. - Т. 45, № 11. - 2004. - С.1303 - 1312.

Новиков И.С. Геоморфологические эффекты внутриконтинентальной коллизии на примере Горного Алтая // Геология и геофизика. - 1996. - № 11. - Т.37. - С. 52 - 60.

Новиков И.С. Кайнозойская сдвиговая структура Алтая // Геология и геофизика. 2001. - № 9. - T. 42. - С. 1377 - 1388.

Новиков И.С. Морфология и история формирования пенеплена Алтая на примере Курайского хребта // Геоморфология. - 2015. - №3. - С. 70-80.

Новиков И.С. Позднепалеозойская, среднемезозойская и позднекайнозойская эпохи орогенеза Алтая // Геология и геофизика. 2002. Т. 43. N 5. С. 434-445

Новиков И.С., Высоцкий Е.М., Каргополов С.А. Геологическое строение, рельеф и неотектоника Чулышманского нагорья (Горный Алтай) // Геология и Геофизика, 2016. T. 57. - №10. - C. 1757 - 1771.

Новиков И.С., Дядьков П.Г., Козлова М.П., Мамедов Г.М., Михеева А.В., Черкас О.В. Неотектоника и сейсмичность западной части Алтае-Саянской горной области, Джунгарской впадины и Китайского Тянь-Шаня // Геология и Геофизика, 2014. T. 55. - №12. - С.1802 - 1814.

Новиков И.С., Жимулев Ф.И., Ветров Е.В., Савельева П.Ю. Геологическая история и рельеф северо-западной части Алтае - Саянской области в мезозое и кайнозое // Геология и Геофизика, 2019. - Т. 60. - № 7. - С. 988-1003.

Новиков И.С., Поспеева Е.В. Неотектоника восточной части Горного Алтая по данным магнитотеллурического зондирования // Геология и Геофизика, 2017. - Т. 58. №7. - С. 959 - 971. 
Новиков И.С., Черкас О.В., Мамедов Г.М., Симонов Ю.Г., Симонова Т.Ю., Наставко В.Г. Основные черты новейшей блоковой делимости Кузбасса // Геология и Геофизика, 2013. - № 3. - Т. 54. - С. 424-437.

Овсюченко А.Н., Рогожин Е.А., Новиков С.С., Мараханов А.В., Ларьков А.С., Акбиев Р.Т., Могушков И.П. Палеогеологические и тектонические исследования сейсмоопасных территорий юга Кузбасса // Сейсмостойкое строительство. Безопасность сооружений. - 2010. - №6. - С. 35-45.

Поспеева Е.В., Витте Л.В., Потапов В.В., Сахарова М.А. Магнитотеллурические исследования в районах новейшей тектоники и сейсмической активности (на примере Горного Алтая) // Геофизика. - 2014. - № 4. - С. 8-16.

Росляков Н. А., Щербаков Ю. Г., Алабин Л. В., Нестеренко Г. В., Калинин Ю. А., Рослякова Н. В., Васильев И. П., Неволько А. И., Осинцев С. Р. Минерагения области сочленения Салаира и Колывань-Томской складчатой зоны: Новосибирск: Издательство СО РАН, 2001. 243 с.

Сваричевская 3.А. Основные этапы развития рельефа юга Западно-Сибирской равнины и ее обрамления // Тезисы докладов совещания по геоморфологии и неотектонике Сибири и дальнего Востока (V пленум Геоморфологической комиссии) Апрель 1965. Новосибирск: Наука, 1965. - С.36-41

Симонов Ю.Г. Основные черты современной концепции дизъюнктивной морфотектоники // Вестник МГУ, сер. геогр., 2003. - № 4. -С. 10-14.

Симонов Ю.Г. Региональный геоморфологический анализ. М.: Изд-во МГУ, 1972. 250 c.

Соколов Н.Н. Геоморфологический очерк района работ Кузнецко-Барнаульской экспедиции // Материалы Кузнецко-Барнаульской почвенной экспедиции 1931 г. Ч.3. - М.: Изд-во АН СССР, 1936. - С.9-20.

Соколов Н.Н. О рельефе Кузнецкого бассейна, Салаира и правобережья Оби // Труды Института физической географии АН СССР, 1935, Вып. 15. - С.5-59.

Сотников В. И., Федосеев Г.С. Кунгурцев Л.В., Борисенко А. С., Оболенский А. А., Васильев И. П., Гимон В. О. Геодинамика, магматизм и металлогения КолываньТомской складчатой зоны. - Новосибирск: Изд-во СО РАН, 1999. - 227 с.

Тимофеев А.В., Ардюков Д.Г., Бойко Е.В., Тимофеев В.Ю., Грибанова Е.И. Современные скорости смещений земной коры Горного Алтая и западного Саяна // Интерэкспо ГЕО-Сибирь-2017. ХІІІ Междунар. науч. конгр. (г. Новосибирск, 17-21 апреля 2017): Междунар. науч. конф. "Недропользование. Горное дело. Направления и технологии 
поиска, разведки и разработки месторождений полезных ископаемых. Экономика. Геоэкология": Сборник материалов. Новосибирск, 2017. - Т.3. - С. 138-143.

Токарев В.Н., Шапилова Г.А., Котик О.П. Государственная геологическая карта Российской Федерации масштаба 1:200000. Издание второе. Серия Кузбасская. Лист N-45XIV (Гурьевск). Объяснительная записка. - СПб.: Картографическая фабрика ВСЕГЕИ, 2002. 188 c.

Токарев В.Н., Юрьев А.А. Косякова Л.Н., Глаас Г.А. Государственная геологическая карта Российской Федерации масштаба 1:200000. Издание второе. Серия Кузбасская. Лист N-45-XXI (Прокопьевск). Объяснительная записка. - СПб.: Картографическая фабрика ВСЕГЕИ, 2019. 210 с.

Туркин Ю.А. Структуры латерального выжимания западной части Алтае-Саянской складчатой области // Геосферные исследования, 2018. - №1. - С.33-43.

Угольная база России. Том. II. Угольные бассейны и месторождения Западной Сибири. - М.: ООО «Геоинфоцентр», 2003. - 604 с.

Усов М.А. Геологическая изученность и задачи ближайших исследований Салаира // Вестник 3СГТ, 1935, №5. - С.3-16.

\section{Ушко К.А., Троцюк В.Я., Сырнев И.П., Ибрагимов Д.М., Рихтер В.Г., Вольперт} М.И., Улицкий Ю.А., Шубников А.А. Методика комплексных структурногеоморфологических исследований при геологопоисковых работах на нефть и газ на примере изучения нефтегазоносных бассейнов юга СССР // Структурногеоморфолдогические исследования при изучении нефтегазоносных бассейнов. - Л.: Издво «Недра» Ленинградское отд., 1967. - С.24-142.

Фомичев В. Д., Алексеева Л. Э. Геологический очерк Салаира. - М.: Госгеолтехиздат, 1961. - 218 с.

Шокальский С.П., Бабин Г.А., Владимиров А.Г., Борисов С.М., Гусев Н.И., Токарев В.Н., Зыбин В.А., Дубский В.С., Мурзин О.В., Кривчиков В.А., Крук Н.Н., Руднев С.Н., Федосеев Г.С., Титов А.В., Сергеев В.П., Лихачев Н.Н., Мамлин А.Н., Котельников Е.И., Кузнецов С.А., Зейферт Л.Л., Яшин В.Д., Носков Ю.С., Уваров А.Н., Федак С.И., Гусев А.И., Выставной С.А. Корреляция магматических и метаморфических комплексов западной части Алтае-Саянской складчатой области. Новосибирск, Изд-во СО РАН, филиал «Гео», 2000, 188 с.

Щуровский Г.Е. Геологическое путешествие по Алтаю. - М.: Унив. тип., 1846. 426 c.

Юзвицкий А. 3. Томский надвиг в Кузбассе Советская геология, 1966, №6, с. 133136. 
Buslov M.M., Semakov N.N., Fujiwara Y., Iwata K. Late Paleozoic -Early Mesozoic geodynamics of Central Asia // Gondwana Research. 2004. v. 7. N 3. p. 791-808.

Cogné J.P., Kravchinsky V.A., Halim N., Hankard F. Late Jurassic-Early Cretaceous closure of the Mongol-Okhotsk Ocean demonstrated by new Mesozoic palaeomagnetic results from the Trans-Baikal area (SE Siberia) // Geophys. J. Int., 2005, v. 163, № 2, P. 813—832.

De Grave J., Buslov M.M., Van den Haute P., Dehandschutter B. Meso-Cenozoic evolution of mountain range - intramontane basin systems in the southern Siberian Altai Mountains by apatite fission track thermochronology//Journal of Asian Earth Sciences. 2007. v. 29. p. 2-9

De Grave J., Van den Haute P., Buslov M.M., Dehandschutter B., Glorie S. Apatite fission-track thermo-chronology applied to the Chulysman Plateau, Siberian Altai Region //Radiation Measurements. 2008. v. 43. p. 38-42

Dehandschutter B., Vysotsky E., Delvaux D., Klerkx J., Buslov M.M., Seleznev V.S., De Batist M. Structural evolution of the Teletsk graben (Russian Altai) //Tectonophysics. 2002. v. 351. p. 139-167

Dobretsov N.L., Buslov M.M., Yu U. Fragments of oceanic islands in accretioncollision areas of Gorny Altai and Salair, southern Siberia, Russia: early stages of continental crustal growth of the Siberian continent in Vendian-Early Cambrian time // Journal of Asian Earth Sciences // V. 23, Issue 5, 2004, P. 673-690.

Glorie S., De Grave J., Buslov M.M., Zhimulev F.I., Elburg M.A., Van den haute P. Structural control on Meso-Cenozoic tectonic reactivation and denudation in the Siberian Altai: Insights from multi-method thermochronometry //Tectonophysics. 2012. v. 544-545. p. 75-92

Haq B.U., Al-Qahtani A.M. Phanerozoic cycles of sea-level change on the Arabian Platform // GeoArabia, 2005. - №10. - 127-160.

Haq B.U., Hardenbol J., Vail P.R. Chronology of fluctuating sea levels since the Triassic (250 million years ago to present) // Science, 1987. - V.235, №4793. - P.1156-1167.

Jolivet M., Brunel M., Seward D., Xu Z., Yang J., Roger F., Tapponnier P., Malavieille J., Arnaud N., Wu C. Mesozoic and Cenozoic tectonics of the northern edge of the Tibetan plateau: fission-track constraints // Tectonophysics, 2001, v. 343, № 1-2, P. 111-134.

Klinger Y., Etchebes M., Tapponnier P., Narteau C. Characteristic slip for five great earthquakes along the Fuyun fault in China // Nature Geoscience, 2011, V. 4, P. 389-392.

Menges C.M. The neotectonic framework of Arizona: implications for the regional character of basin-range tectonism. Open-File Report 83-19. - Arizona Geological Survey, 1984. -109 p. 
Miller K.G., Mountain G.S., Wright J.D., Browning J.V. A 180-million-year record of sea level and ice volume variations from continental margin and deep-sea isotopic records // Oceanography, 2011. - V.24, №2. - P.40-53.

Molnar P., Tapponnier P. Cenozoic tectonics of Asia: effects on a continental collision // Science, 1975, v. 189, p. 419-426.

Novikov I.S., Sokol E.V. Combustion metamorphic events as age markers of orogenic movements in Central Asia // Acta Petrologica Sinica. - 2007. - V.23. - № 7. - P. 1561 - 1572.

Radaideh O.M.A., Grasemann B., Melichar R.,Mosar J. Detection and analysis of morphotectonic features utilizing satellite remote sensing and GIS: An example in SW Jordan // Geomorphology, 2016. - V. 275. P. 58-79

Shi J., Feng X., Ge S., Yang Z., Bo M., Hu J. The Fuyun earthquake fault zone in Xianhiang, China // Continental Seismicity and Earthquake Prediction Beijing: Seismological Press, 1984. - P., 325-346.

Staškovanová V. and Minár J. Modelling the geomorphic history of the Tribeč Mts. and the Pohronský Inovec Mts.(Western Carpathians) with the CHILD model // Open Geosciences, 2016. - V. 8. - P. 371-389.

Vail P.R., Mitchum R.M. Jr., and Thompson S. III Seismic stratigraphy and global changes of sea level. Part 4. Global cycles of relative changes of sea level // American Association of Petroleum Geologists Memoir, 1977. - V.26. - P.83-89.

Yin A., Harrison T.M. Geological evolution of the Himalayan-Tibetan orogeny // Ann. Rev. Earth Planet. Sci., 2000, v. 28, P. 211-280.

Zernitz E.R. Drainage Patterns and Their Significance // Journal of Geology. - V.40, № 6. - 1932. - P. 498-521.

Zhimulev F.I., Gillespie J.A., Glorie S., Jepson G., Vetrov E.V., De Grave J.,. Tectonic history of the Kolyvan-Tomsk folded zone (KTFZ), Russia: Insight from zircon U/Pb geochronology and Nd isotopes. - Geological Journal 2020, №55, P. 1913-1930. 


\section{Подрисуночные подписи}

\section{Рис. 1. Схема расположения Салаирского кряжа и впадин в его обрамлении.}

1-2 границы впадин: 1 - ранне- и среднеюрских, 2 - поздненеогеновых; 3 - границы современного Салаирского кряжа;

4-5 - элементы современной гидрографии: 4 - озера и водохранилища, 5 - реки, 6 гипсометрические отметки в м.

Рис. 2. Схема положения Салаира в геоморфологической структуре региона (A), ее отображение на космоснимке LANDSAT (B).

Красным контуром показаны орографические границы Салаирского кряжа.

Буквенными индексами обозначены орографические элементы: межгорные котловины: К - Кузнецкая, НЧ - Ненинско-Чумышская; возвышенности: БС - БуготакскоСокурская; предгорные равнины: БЧ - Бийско-Чумышская, ПП - Приобское плато; флювиальные равнины: ВО - Верхне-Обская; горные сооружения: С - Салаирский кряж, ГШ - Горная Шория, КА - Кузнецкий Алатау.

1 - элементы современной гидрографии, 2 - геоморфологические элементы: аккумулятивные $\mathbf{a}$ - эоловые равнины, $\mathbf{b}$ - аллювиальные равнины, $\mathbf{c}$ - древние ложбины стока (катафлювиальные равнины); денудационно-аккумулятивные: d - пластовые равнины, е -пластовые равнины под лессовым покровом; f - пенеплен по раннемусреднему палеозою под лессовым покровом, g - пенеплен по позднему палеозою и мезозою под лессовым покровом; денудационные: h - пенеплен по раннему-среднему палеозою, $\mathbf{i}$ - пенеплен по позднему палеозою и мезозою, $\mathbf{j}$ - низкогорье, $\mathbf{k}$ - среднегорья;

Рис. 3. Неотектонические блоки Салаира и их распределение по линейным размерам

Распределение блоков по длине (B), ширине $(\mathbf{L})$, площади (S); $\mathbf{H}$ - группировка блоков по высоте, цифры на изображении блоков - высоты вершинной поверхности в м.

Фиолетовыми п пронумерованными точками показаны профили магнитотеллурического зондирования (Жимулев и др., 2021). Числа рядом с точками профилей - номера пунктов магнитотеллурического зондирования, цветом и изолиниями на профилях показано удельное сопротивление в Ом`м.

Рис. 4. Схема соотношения докайнозойской сети разломов Салаира с разломными границами неотектонических блоков 
1-2 - элементы гидрографии 1 - озера, 2 - реки, 3 - границы распространения неогенового чехла Бийско-Барнаульской впадины, 4-7 - границы неотектонических блоков (показаны только для территории Салаира): 4 - неустановленной кинематики, 5 - правые сдвиги и взбрососдвиги, 6 - взбросы и надвиги, 7 - сбросы; 8-10 докайнозойские разломы (показаны для всей территории): 8 - неустановленной кинематики, 9 - взбросы и надвиги, 10 - сбросы.

Буквами на схеме обозначены: КT - Колывань-Томская складчатая зона, К Кузнецкая впадина, С - Салаирский складчато-покровный блок, ББ - БийскоБарнаульская впадина, НЧ - Ненинско-Чумышская впадина. 

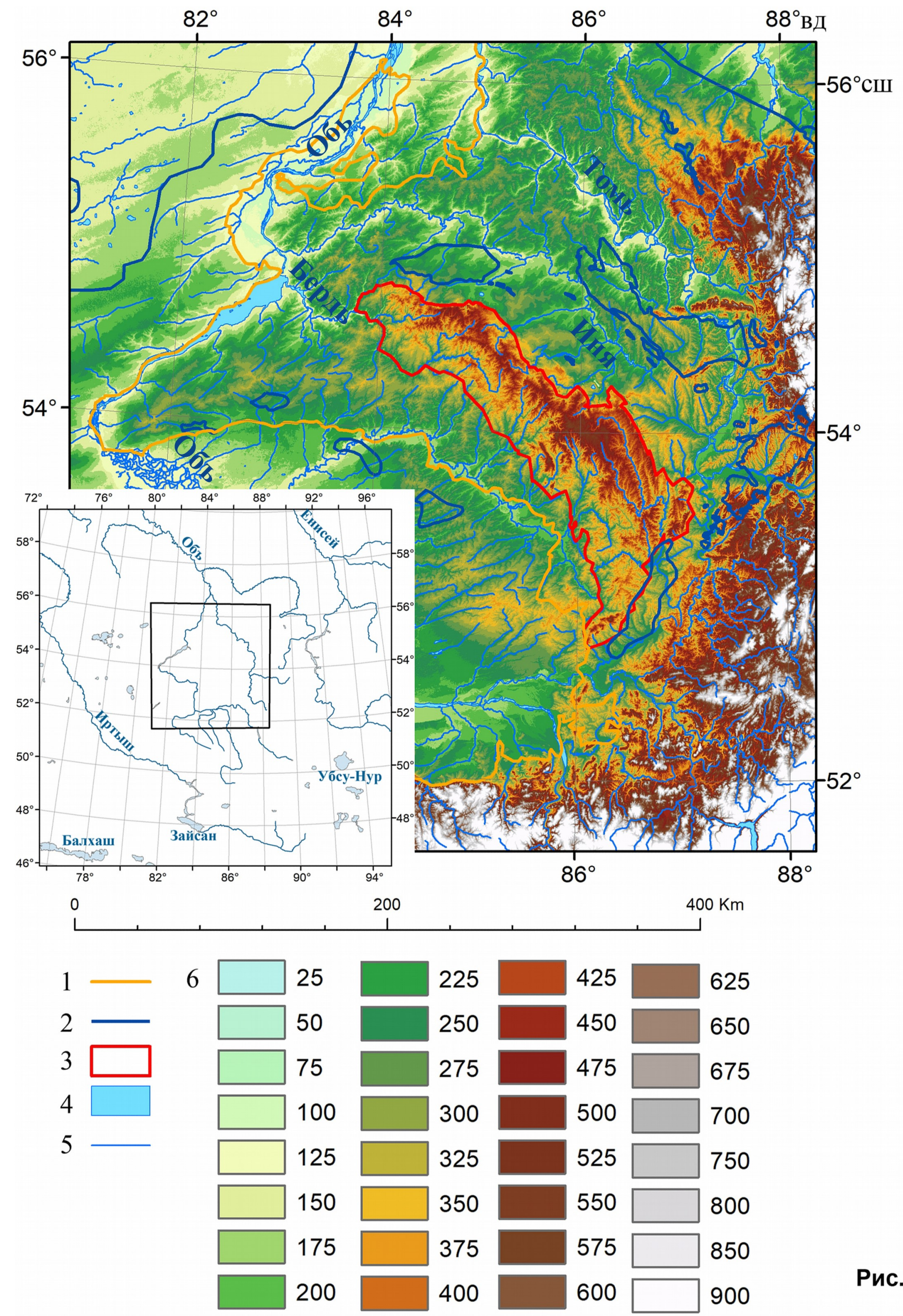

Рис. 1 

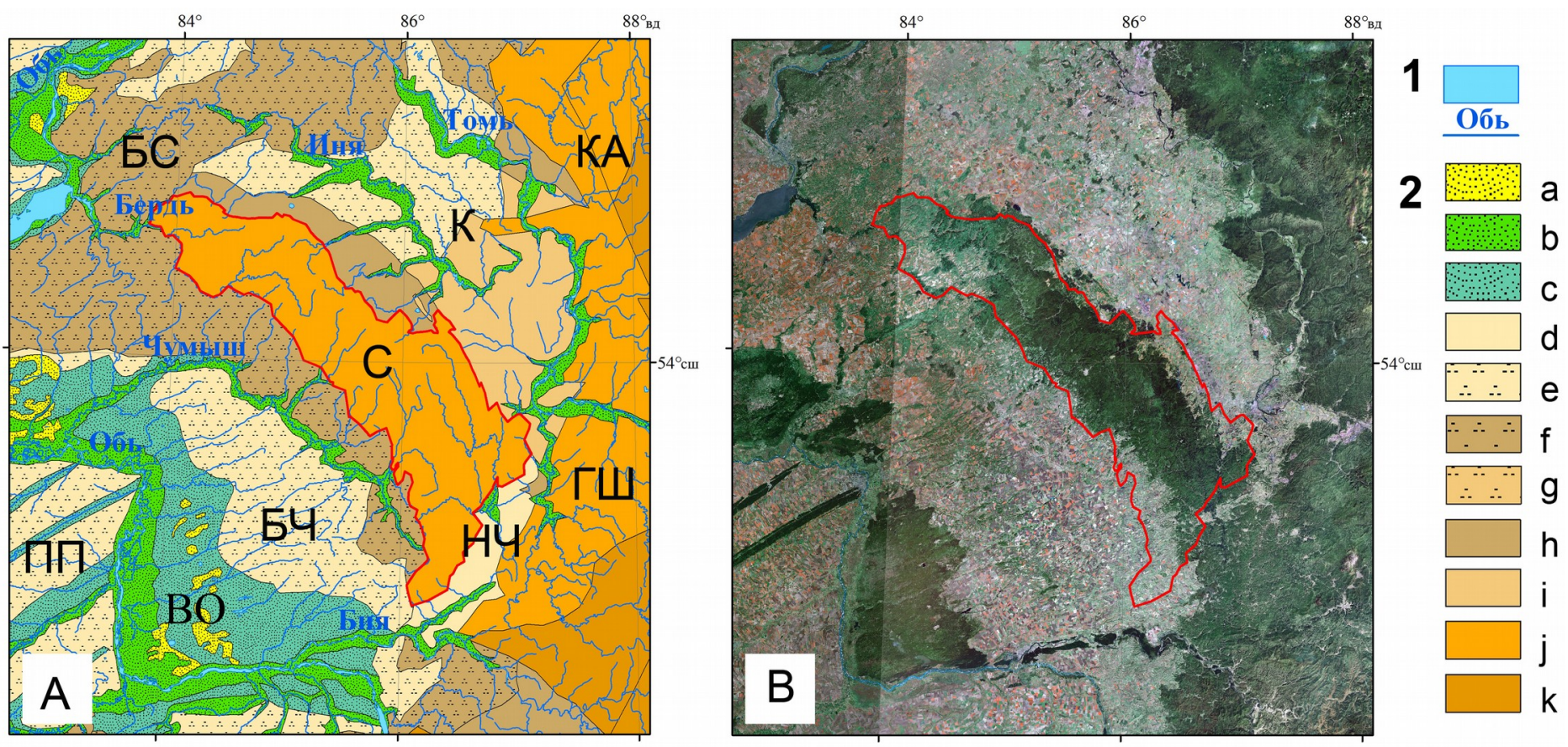

0

100 200 KM

Рис. 2 


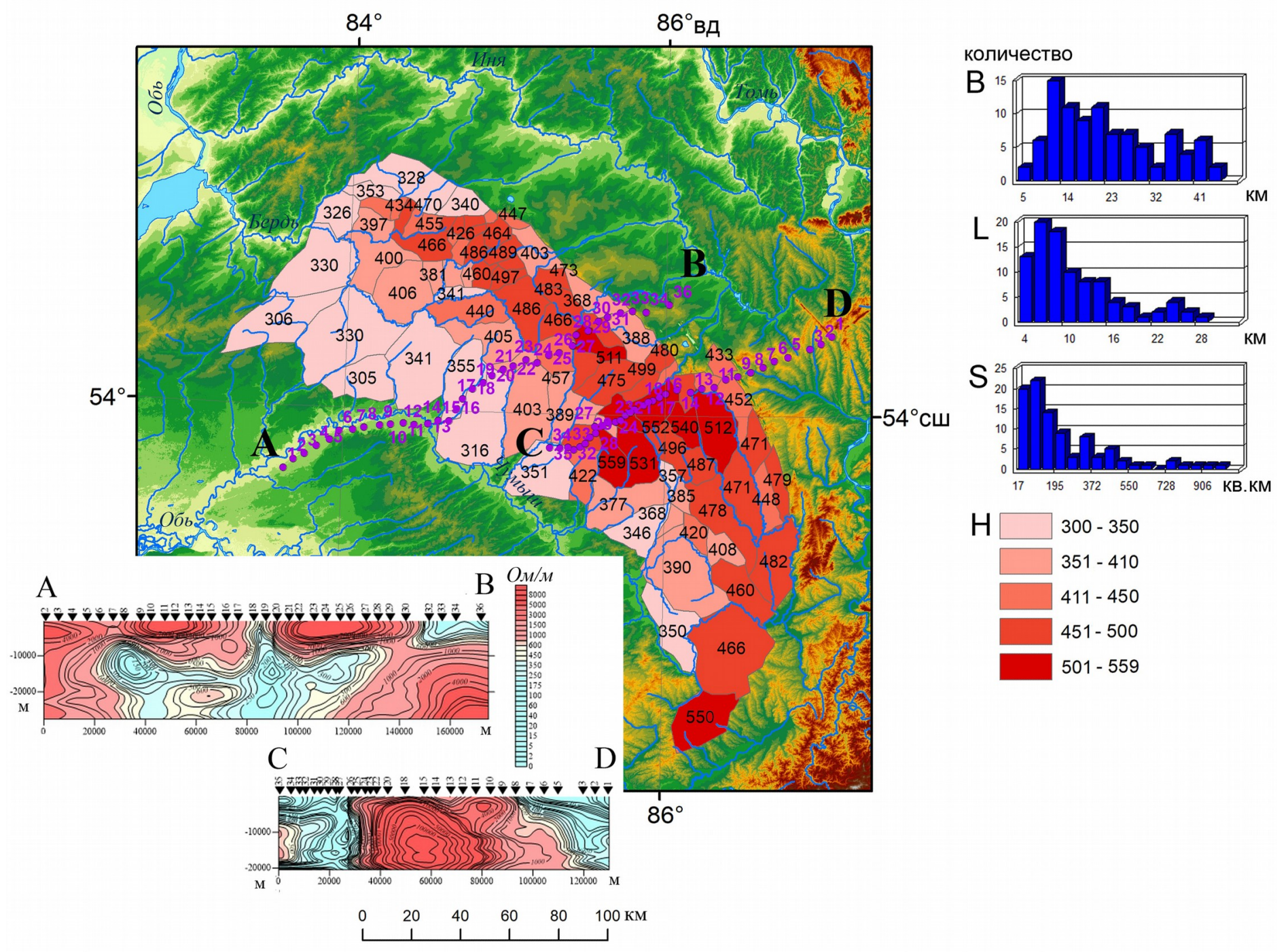




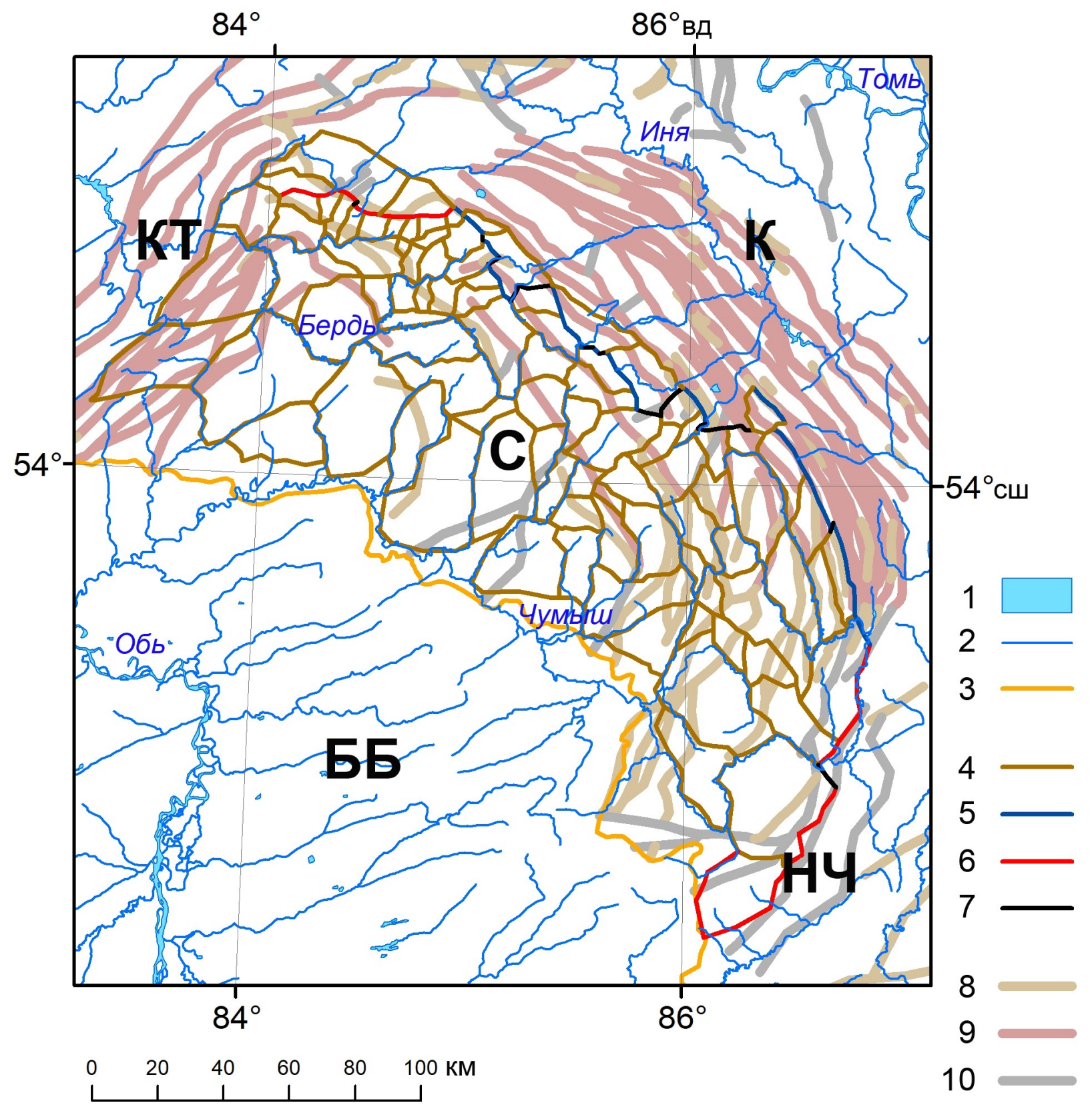

